\title{
Social Psychological Factors Behind Ethnic Discrimination in Employee Selection
}

\author{
Z.Maviş Yıldırım* \\ Bursa Uludă̆ University
}

\author{
Funda Turhan** \\ Bursa Uludă̆ University
}

\author{
M.Ersin Kuşdil*** \\ Bursa Uludă̆ University
}

\begin{abstract}
The present study examines the social psychological factors behind the ethnic discrimination of Kurdish groups in organisations by applying audit studies. The hypotheses derived from Social Identity and Social Dominance theories were tested in two studies. The findings revealed that the employment chances of candidates from the Southeastern province of Turkey where a sizable Kurdish population lives is significantly lower than those from other regions. The finding that decision-makers maintain a high level of social distance from the Kurdish ethnic group when compared to other social groups points to a tendency to discriminate against Kurdish people.
\end{abstract}

Keywords: Ethnic discrimination; social identity; social dominance orientation; decision-makers; minority groups; employee selection.

JEL Classifications: J7, J71, M54

\section{Çalışan Seçiminde Etnik Ayrımcılığın Arkasındaki Sosyal Psikolojik Faktörler}

Özet

$\mathrm{Bu}$ çalışma, organizasyonlarda Kürt etnik grubuna karşı etnik ayrımcılığın ardındaki sosyal psikolojik faktörleri "saklı seçim testleri" (audit studies) kullanarak incelemiştir. Sosyal Kimlik ve Sosyal Baskınlık teorilerinden elde edilen hipotezler iki çalışmada test edilmiştir. Bulgular, kalabalık bir Kürt nüfusun yaşadığı Güneydoğu Anadolu bölgesinden olan adayların istihdam şansının diğer bölgelerden olan adaylara göre daha düşük olduğunu ortaya koymuştur. Karar vericilerin, Kürt kökenli adaylara karşı, diğer etnik gruplarla kıyaslandığında, daha yüksek bir sosyal mesafeyi korudukları bulgusu Kürt kökenli bireylere karşı ayrımcılık yapma eğilimine işaret etmektedir.

Anahtar Kelimeler: Etnik ayrımcılı;; sosyal kimlik; sosyal baskınlı yönelimi; karar vericiler; dezavantajlı gruplar; çalışan seçimi.

JEL Sinıflandırması: J7, J71, M54

\footnotetext{
* Z.Mavis Yıldırım, Ph.D. Department of Labour Economics \& Industrial Relations. Bursa Uludag University. Gorukle Campus, 16059. Bursa. Turkey. E-mail: mavisyildirim@uludag.edu.tr. ORCID: 0000-0001-7667-9724

** Funda Turhan, Ph.D student. Department of Psychology. Bursa Uludag University. Gorukle Campus, 16059. Bursa. Turkey. Email: funda.gnc5@gmail.com. ORCID: 0000-0001-5857-606X *** M.Ersin Kuşdil, Professor. Department of Psychology. Bursa Uludag University. Gorukle Campus, 16059. Bursa. Turkey. E-mail: kusdil@yahoo.com. ORCID: 0000-0002-3005-9009
} 
$\mathrm{T}$

he present study examines potential ethnic discrimination practices that are assumed to be in the Turkish workplace and the effects of the social psychological reasons behind these practices on the employment opportunities of the Kurdish ethnic group. The research focuses on possible ethnic prejudices that may affect Kurds' recruitment prospects in the local Turkish automotive industry. It tries to predict discrimination in employment processes by drawing upon two important theoretical frameworks within the social psychology discipline, namely the social identity approach and social dominance theory. This study was planned as an audit study, a specific type of field experiment that is used to detect latent determinants of discrimination such as social distance to disliked groups. Audit studies are widely used to estimate the overall level of discrimination against specific groups in the decision-making processes of different markets such as labour and housing (Gaddis, 2018; Neumark, 2011:1130). The present study applied this method to examine discriminative tendencies based on ethnicity in the employment phase in a Turkish context.

Discrimination encountered in working life should be considered as a multi-factor phenomenon. Discrimination practices can occur at cultural, social, institutional and individual levels (Dovidio and Hebl, 2005). Although the "right to work" and "rights at work" are enshrined, recognized and protected in many international, regional and national treaties, constitutions, articles, etc., it would appear that these, and many other legal instruments, lack the clout to protect individuals and groups of people from discrimination in the employment processes.

Discrimination in the workplace prevents workers from gaining access to the jobs they desire, blocks opportunities to develop their skills and limits the chances of workers to obtain the knowledge and experience necessary for career development (Marchington and Wilkinson, 2002). Wen and Madera (2013) examined the career prospects of minority students studying in the hospitality industry and whether ethnic minority students faced more obstacles than white students in this sector. The results showed that ethnic minority students were more discriminated against in the accommodation sector than White students, and faced more access barriers. In addition, there was a negative social stamp associated with being a minority and working in the hospitality industry. Fearfull and Kamenou's (2010) study examining the working and career experiences of men and women belonging to ethnic minority groups in Belgium, Germany and England produced similar finding: ethnic workers belonging to minority groups reported experiences of differential treatment in terms of career quality and opportunity.

Workplace discrimination against individuals has negative outcomes in terms of attitudes towards jobs, psychological and physical well-being and work-related outcomes and these outcomes affect both workers and the organisations in a negative way (Marchington and Wilkinson, 2002; Triana, Jayasinghe and Pieper, 2015). Research shows that employees who have been victims of discrimination experience psychological problems. Discrimination causes stress, demoralization and motivation deficiencies in individuals (Feng and $\mathrm{Xu}, 2014$; Hassan et al. 2013; Rousseau et al. 2011; Ajrouch et al., 2010; Corning, 2002). Victims of discrimination develop a decrease in self-esteem, feelings of helplessness and character disorders (Elmslie and Sedo, 1996), which lead to a decrease in productivity among deprived workers and has significant negative effects on job satisfaction (King et al. 2012) and psychological well-being (Taylor, McLoughli, Meyer and Brooke, 2013; Benner et al., 2018; Deitch et al., 2003; Jasinskaja-Lahti, Liebkind, and Perhoniemi, 2007). Jasinskaja-Lahti, et al. (2007) also provide similar findings about the negative effects of perceived discrimination and unemployment on the psychological well-being of immigrants. 
Discrimination in the labour market affects not just individuals but beyond that has a greater impact on minority groups by creating inequalities in multiple domains of social life, including education, housing, healthcare and the judicial system, among others. Discrimination is defined as unfair and negative actions against individuals or against members of different social groups: it is the condition of not being treated (Allport, 1954; Göregenli, 2012; Fiske, 1998; Macionis, 2013). Today's industrial society model causes social classes to emerge as economic groups in working life. This model gives institutions the power to intervene, transform and manage the lives of individuals and groups in the community. Therefore, institutional behaviour in working life also constitutes one of the most important factors in the construction of social equality. When minority groups have no access to employment opportunities due to discrimination, this causes much deeper social problems for minority groups. Any obstacle to employment or any form of economic exclusion can lead to chronic unemployment among the members of minority groups, which in turn results in cultural, political and spatial exclusion, especially for immigrants and ethnic minority groups (Buğra and Keyder, 2003). As a result of this vicious circle, the ties such groups have with society weaken in the long term, leading to poverty in the form of social deprivation (Akkan, Deniz and Ertan, 2011). There is a long-observed link between discrimination and poverty, with discrimination having been identified as both a cause and a result of poverty (Lang, 2007; Akkan, et al., 2011). The Apartheid regime in South Africa is a well-known example of this link between discrimination and poverty: The systematic discrimination against blacks eventually led to economic deterioration by reducing the quantity of qualified workers (ILO ITC, 2009). To address this issue, it is necessary for states to come up with policies that take into account the needs of society's minority groups.

In this globalized world where multi-cultural societies and organisations are constantly on the increase, diversity can have a significant effect on the workplace, both positive and negative. Studies show that though diversity is beneficial for increasing organisational effectiveness (Dadfar and Gustavsson, 1992), it may also have some detrimental effects on organisational cohesion by limiting the possibilities for efficient communication within organisations. The findings show that this may lead to some inter-personal barriers and adaptation problems that in turn increase conflict (King, Hebl, and Beal, 2009; Milliken and Martins, 1996) and employee turnover (Jackson et al, 1991).

Turkey is a multi-ethnic society, with 47 identified different ethnic groups (Andrews, 1992). These groups are of different sizes with Turks constituting the majority of the population and Kurds the largest of the minority groups. A recent survey shows that Kurds constitute 14 per cent of Turkey's population whereas the number of Turks is around 74 per cent (KONDA, 2010). The present study aims to examine the possible discriminative tendencies of decisionmakers in Turkey by focusing on prejudice towards this group of people.

Over the past 40 years, millions of Kurds migrated to major cities such as Istanbul, Ankara, Izmir, Bursa and Adana, mainly in search of employment and to escape reginal clashes between the state and the separatist Kurdish movement. As it is known, perceived threats have the power to trigger prejudice between social groups (Stephan and Stephan, 2000; Stephan and Renfro, 2002). In spite of approximately 4 million people having Turkish and Kurdish kinship relations (KONDA, 2010), it seems that the level of prejudice against Kurds has risen in recent years due to the armed conflict that have taken place mostly in the Southeastern region of Turkey where most Kurds live.

In one of the few studies focusing on prejudices against Kurds, Saraçoğlu (2011) found that the image (or the stereotype) of "Kurdishness" in Izmir included "ignorance, unfair earning, separatism and occupiers of the city" (p. 23). For Saraçoğlu, the underlying causes of 
this negative change in the middle class perception towards Kurds in Izmir should be understood through migration, economic transformations and changing class relations in social life. It seems that such prejudices are also prevalent in Turkey's labour markets. Lordoğlu and Arslan (2012) focus on the practice of ethnic discrimination in the labour markets of six Turkish cities selected in the Southeast with predominantly Kurdish populations and in Western regions with mostly Turkish populations. Results show that ethnic discrimination practices were quite common in both regions of Turkey and that their effects are seen in the people's participation in labour markets; their opportunities for promotion in the workplace; the reasons for leaving jobs and for being out of the labour market for a long time (see also, Altuntaş, 2014; Saraçoğlu, 2011).

Although they provide valuable information about discrimination and prejudice towards Kurds, these studies do not explain the basic psychological dynamics that govern the discriminative tendencies of majority members when evaluating members of Kurdish groups while distributing resources such as jobs and higher positions. Therefore, there is merit in examining the effects of the prejudiced attitudes of decision-makers towards minority members when selecting employees for their organisations.

\section{Theoretical Background}

Although social psychologists are recognized by other social scientists as the forerunners in studies on the problems of discrimination, there have been serious disagreements among them regarding the source of this phenomenon. In one camp, social psychologists believe that focus should be on the individual as discriminative practices are a reflection of inner psychological states, ranging from cognitive to emotional (i.e. the social cognition approach) whereas members of the other camp assert that such an approach is overly reductionist as it underestimates the effects of wider social contexts (i.e. the inter-group approach). Proponents of the social cognitive approach, therefore, tend to criticize the inadequate focus of antidiscriminative programs that are limited to more conventional forms of prejudice (for example, Fiske, Cuddy, Glick and Xu, 2002; Morris and Fiske, 2009). On the other hand, the inter-group approach proponents propose that prejudices are partly the by-products of hierarchical nature of societies (for example, Tajfel and Turner, 1979; Sidanius and Pratto, 1994). Despite their disagreements on where to search for the real cause of discriminatory practices, most social psychologists study the issue by using similar concepts such as implicit or explicit forms of stereotypes and prejudices (Allport, 1954; Dovidio, 2001; Fiske, 1998; Paker, 2012). In the present study, the inter-group approach is preferred over the social cognition approach as it provides ways for integrating individual-level and group (or societal)-level factors.

\section{Inter-group Approaches to Discrimination}

In recent decades, two theories have stood out as leading theoretical frameworks for understanding the complex nature of prejudice and discrimination in the area of social psychology: Social Identity Theory and Social Dominance Theory (Huddy, 2004). These theories differ from others in their multi-level approaches to intergroup behaviours, which range from individual to ideological levels. 
The Social Identity Approach. This theoretical framework initially intended to explain the phenomena of intergroup conflict and social change (Tajfel and Turner, 1979), but later, Turner (1999) made a detailed analysis of the psychological processes assumed to be responsible for macro-level dynamics in his "self-categorization theory". Today, as social identity theorizing grows continuously, different versions or extensions of the original theory are categorized under the term the social identity approach (SIA, Hornsey, 2008). In general, SIA assumes that human beings are "social" creatures in the sense that their selves must be defined by their social identities together with their personal qualities. Social identities derived from their group memberships form an indispensable part of the self-conceptions of individuals (Hogg and Vaughan, 2007).

SIA assumes that individuals have a need for self-esteem, and seek to protect it under changing social circumstances. The self-esteem of the individual is related directly to their group memberships as these carry a number of positive or negative valences that are derived from the hierarchical organisation of the group structure. In the first step, each individual in a society categorizes himself/herself and others according to several social categories, and this process of social categorization opens the way for several comparisons of in- and out-groups by individuals to define the valences of social identity. As a rule, a negative result motivates an individual to take action to find a solution through the use of strategies that may range from being individual to group-based, depending on his/her level of identification with the in-group (Tajfel and Turner, 1979, Jackson and Harnish, 1996; Mummendey, Kessler, Klink, Mielke, 1999, Glasford, Dovidio, Pratto, 2009). However, any attempt of minority groups to change the status quo inevitably produces a counter-reaction from members of the advantaged group, ranging from mild (accepting superiority of a minority group in some trivial aspects used in inter-group comparisons) to more radical actions and/or tactics (showing fierce resistance to change by all means including oppression/violence), especially from members of the advantageous group who are highly identified with their in-group. The dimensions used in inter-group comparisons may vary from one society to another due to their different histories and circumstances. While ethnicity may be the salient dimension for one society, the race dimension may be the most important for another (Tajfel and Turner, 1979; Hogg, Abrams, Otten and Winkle, 2004). Consequently, the social distance perceptions of advantaged/minority group members may vary in different societies due to their unique historical contexts.

SIA theorists consider prejudice and discrimination to be an inevitable result of the above-mentioned dynamics. In-group favouritism, which is a natural outcome of identification with in-groups, paves the way for conflictual relations between opposing groups as each tries to retain material and symbolic resources for themselves. Prototypes are mental products that make it possible for group members to define common in-group and out-group characteristics (Turner, 1999; Hogg and Reid, 2006).

From a SIA perspective, inequalities observed in employment can be regarded as an indirect result of in-group favouritism. As unity among members of an advantaged group increases, they tend to discriminate against members of the minority group. Stereotypes, as a main component of group prototypes, are used as a knowledge base for discriminative behaviour. In this sense, at the individual level, in-group identification is closely related to the increase in discriminatory behaviours and attitudes among groups. Research shows that high in-group identifiers discriminate more than low in-group identifiers (Perreault and Bourhis, 1999; Gagnon and Bourhis, 1996). On the other hand, as a well-known example of an interactionist perspective that focuses on the dynamic nature of the relationships between the person (or group) and the changing context (for example, economic situation), SIA proposes that revisions in prototypes due to changing inter-group relations are possible. Thus, they may 
discourage individuals from behaving in a discriminative way when their groups sanction such practices normatively (Wyer, 2010).

Social Dominance Theory. The other well-known social psychological approach to the issues of prejudice and discrimination is the social dominance theory (SDT) proposed by Sidanius and Pratto (1999). Social dominance theorists regard societies as hierarchically organized structures that depend upon three group-based social hierarchies: age, gender and arbitrary-set systems. In the age and gender systems, adults and men wield disproportionate social power over young people and women. The arbitrary-set system, however, is quite different as it is "filled with socially constructed and highly salient groups based on characteristics such as clan, ethnicity, estate, nation, race, caste, social class, religious sect, regional grouping, or any other socially relevant group distinction ... In such systems, one group is materially and/or politically dominant over the other" (Sidanius and Pratto, 1999, p. 33).

Sidanius and Pratto claim that through their occupation of the main economic, political and social roles in society, dominant groups have the power to control the resources of other less advantageous groups with nepotism being a manifestation of this disproportionate control of resources. As a result of this, minority groups are burdened with such problems as poverty, unemployment and dangerous working conditions (Sidanius and Pratto, 1999; Pratto, Sidanius and Levin, 2006).

A group-based social hierarchy is supported by the use of legitimizing myths, which "consist of attitudes, values, beliefs, stereotypes, and ideologies that provide moral and intellectual justification for the social practices that distribute social value within the social system" (Sidanius and Pratto, 1999, p. 45). Legitimizing myths that justify and support social inequalities are referred to as hierarchy-enhancing legitimizing myths (HE-LMs), whereas those that support and justify greater levels of group-based social equalitarianism are referred to as hierarchy-attenuating legitimizing myths (HA-LMs).

The individual-level aspect of social dominance theory is the concept of social dominance orientation (SDO), which is defined as "the degree to which individuals desire and support group-based hierarchy and the domination of 'inferior' groups by 'superior' groups" (Sidanius and Pratto, 1999, p. 48; Pratto, Sidanius, Stallworth and Malle, 1994). The theory assumes that members of more dominant groups tend to have higher levels of SDO than those of minority groups (Pratto et al., 2006). Drawing upon the links between group-based hierarchies and institutions, Sidanius and Pratto (1999) assert that key institutions (such as judicial, security, military, educational, etc.) tend to select high SDO individuals in an effort to maintain and protect group-based social hierarchies, and these individuals are expected to demonstrate higher levels of prejudice and discrimination against members of minority groups (Pratto et al., 1994; Pratto et al., 2006; Kteily, Sidanius, Levin, 2011; Michinov, Dambrun, Guimond and Meot, 2005). The deteriorating effect of high SDO is expected to reveal itself even in daily life by increasing social distance perceptions of the advantageous group's members (see, Follmer and Jones, 2017). In contrast, low SDO members of advantageous group tend to struggle against such inequalities by taking over roles that diminish the effects of HE-LMs and practices in their institutions (Pratto et al., 2006; see also, Sidanius, Liu, Shaw and Pratto, 1994).

Research into the relationship between SDO and selection, however, are scarce. In an experimental study, Umphress, Simmons, Boswell and Triana (2008) show that high SDO participants reported that they were less likely to select a potential team member who is a member of a low-status group (females and black males) than those low in SDO. However, explicit directives from an authority figure to base their choices on legitimate performance criteria when evaluating job candidates had the power to diminish the discriminative tendencies 
of high-SDO participants. This finding indicates that organisations' characteristics are also important in creating an environment that paves the way for discriminative practices.

\section{The Study}

Discriminative practices are widespread in many aspects of social life, including education, labour markets, criminal justice, health care, housing-mortgage markets, etc. (Blank, Dabady and Citro, 2004). Although the key actors are different in such sectors, the main theme in the basic processes is similar in that they aim to protect and maintain the status boundaries between groups as intact and impermeable. In the present study, the focus is on the discriminative tendencies of "decision makers" in hiring individuals from minority groups. It is proposed that the general tendencies of decision makers, or decision-makers as key actors in labor markets, can be examined through the use of the key concepts developed by SIA and SDT.

Apart from its importance for individuals and societies, research on discrimination against minority groups in the workplace has its unique difficulties and challenges. It is known that the phenomenon of workplace discrimination is quite elusive. As discrimination is a socially unacceptable form of behaviour, it tends to emerge in hidden forms and builds an invisible wall that minorities feel themselves on the weak side of in the balance of power in society and workplaces (Van-Laer and Janssens, 2011). Therefore, only methodologically sound studies that draw upon well-established theories that explain the phenomenon by integrating the personal and contextual factors can capture the dynamics behind real situation in the workplaces. The present study aims to explore the individual determinants of discriminative tendencies (i.e. prejudices) within the organizational context by assuming that the general organizational climate may curb or motivate such inclinations.

In order to reach this aim this study focuses on the prejudices of decision-makers in automotive companies located in Bursa, one of Turkey's main industrial cities, which has a population of over 3 million people (TÜİK, 2019), including a sizable Kurdish community like other big Turkish cities such as Istanbul, Ankara and Izmir. The main purpose of this study is to determine whether gatekeepers in institutions demonstrate discriminatory attitudes towards and make discriminatory evaluations of Kurdish candidates and to examine the social psychological factors underlying such discriminatory attitudes and negative evaluations. By deriving testable hypotheses from SIA and SDT, an attempt is made to predict the basic psychological dynamics behind the employment practices of gatekeepers involved in employee selection procedures. The following hypotheses that are derived from the literature were tested in the present study:

First of all, although some studies have showed that this could be the case (Saraçoğlu, 2011; Lordoğlu and Arslan, 2012), it is necessary to test the assumption that decision-makers in Bursa are prejudiced against Kurds. In order to do this, the decision-makers' social distance from the Kurdish group is selected as an indirect reflection of their prejudiced attitudes. It is expected that the decision-makers' social distance from the Kurdish ethnic group will be significantly higher than their social distance from the Turkish group (Hypothesis 1). Depending on the ideas that have been put forward by SIA and SDT, another expectation is formed: As the level of identification and SDO of decision-makers increases, their expectations about the employment chances of candidates of Southeastern origin decrease, at both personal and institutional levels (Hypothesis 2). In a related hypothesis, it is expected that the employment chances of candidates originating from the Southeast as perceived by the decisionmakers will be significantly lower than those of candidates from the other regions of Turkey, both at personal and institutional levels (Hypothesis 3). Lastly, by considering the possibility that the norms of organisations that prohibit discriminative practices may curb individuals' tendencies to favour members of their in-groups in employee selection, another hypothesis is 
formed: There will be a positive and significant correlation between the decision-makers' beliefs that the equal occupational opportunity policy is observed in their workplace and the employment opportunities open to candidates of Southeastern origin, both at personal and institutional levels (Hypothesis 4).

\section{Method}

This research comprised two studies: The first of these was a pilot study, in which the social distance felt towards the minority groups of Turkey including Kurds were examined by using data from a general sample from Bursa, the city where the sample of decision-makers was derived for the main study. The second concerned the testing of the photographic material that was planned to be used in the main study.

The second study was the main one realized to test the hypotheses of the present research. In the main study, designed as an audit study, decision-makers' tendencies in selecting candidates from the Southeast of Turkey (the origin of most Kurdish people) were studied by using fictional CVs with photographs sourced by the researchers in the pilot study. In addition, a questionnaire that included measures for in-group identification, SDO, and perceptions towards the equal occupational opportunity policies provided by the gatekeeper's workplace was administered in the main study.

\section{Pilot Study}

\section{Sample}

The sample was comprised of 100 people (40 female, 59 male, 1 unspecified) of varied ages and employed in a variety of occupations, all of whom were residents of Bursa and participated in the study voluntarily. The sample was assembled using the "convenience sampling" technique.

\section{Instruments}

Photographs. After receiving their written consent, photographs were taken of 12 men whose facial characteristics were believed to correspond to Kurdish and Turkish stereotypes that are prevalent in the Turkish society (Turkish people are thought of as having a lighter skin color compared to Kurdish people). In order to test the initial expectations regarding the researchers' choice of individuals, the photographs were lined up in random order on the questionnaire forms and seven questions were asked about each photograph. The first question was "What is the likelihood of the person in the photograph being from the Southeastern Anatolian region of Turkey, or from the Western Anatolian region of Turkey?". Participants rated these likelihoods separately on two 7-point scales $(1=$ Very Low; $7=$ Very High $)$. The form also included five further questions related to the perceived social characteristics of the people in these pictures: Participants were asked to rate the likelihood of the people in the photographs [1] being married, [2] being wealthy, [3] being successful in the workplace, [4] having good relationships and [5] having a university education, each of which was assessed by them on a 7-point scale $(1$ = Very Low; 7 = Very High $)$.

Social Distance Scale. In order to measure the distance felt by the participants to the ethnic groups living in Turkey, a set of ethnic groups were specified by drawing upon the results of KONDA's (2006) large-scale survey realized by forming a representative sample in Turkey. Findings of KONDA's survey showed that the distribution of ethnic groups in Turkey was as follows: $81.33 \%$ Turkish; $9.02 \%$ Kurdish; $0.62 \%$ Balkan-origin and immigrant $0.75 \%, 0.27$ $\%$ Arabian, $0.10 \%$ Caucasian-origin, $0.03 \%$ Romani and Non-Muslim $(0.08 \%$ Armenian, $0.01 \%$ Greek [Rum] and Christian, 0.004 Jewish \%, $0.004 \%$ Assyrian). Based on these findings, the Turkish, Kurdish, Laz, Armenian, Albanian, Arabian, Circassian, Greek and 
Romani groups were selected for the Social Distance Scale based on their population size and their relevance in the composition of the population of Bursa. With this instrument, the aim was to understand the level of social contact the respondent would prefer to maintain with members of these ethnic groups using a 7-point scale $(1=I$ would marry a member of this group; 7 = I wish the members of this group would get out of my country).

Demographic Form. Participants of the pilot study were asked about their age, gender, education level and occupation. No further question that may reveal their personal identity was asked in the questionnaire.

\section{Results of the Pilot Study}

Twelve paired-sample t-tests were conducted to compare the probabilities given by the respondents regarding the region of origin (Southeastern or Western Anatolia) of the people in the 12 photographs. The results of these analyses revealed that four of the persons in the photographs were evaluated as more likely to be of Southeastern rather than Western Anatolian origin and seven of those photographed were evaluated as being more likely to be from Western Anatolia (for means and the results of t-tests, see Table 1). As there was no significant difference in relation to origin, one photograph was removed from the set. After sorting the remaining eleven pictures with regard to their mean scores, eight photographs (three representing Southeasterner characteristics and five representing Western characteristics were selected for the fictional CVs to be used in the second study. The numbers of photographs representing people from each origin were intentionally kept unequal (four for Southeastern, seven for Western Anatolian) in order to conceal the aim of the study as much as possible.

Table 1 T-test comparisons of participants' evaluations of the persons in the photographs for their probability of coming from Western and Southeastern Anatolia regions

\begin{tabular}{ccccc}
\hline $\begin{array}{c}\text { Photo } \\
\text { No }\end{array}$ & $\begin{array}{c}\text { Southeastern } \\
\text { Anatolia Region } \\
\text { Mean }(\text { SD) }\end{array}$ & $\begin{array}{c}\text { Western Anatolia } \\
\text { Region } \\
\text { Mean }(\text { SD })\end{array}$ & $\begin{array}{c}\text { Difference of } \\
\text { Means }\end{array}$ & $\boldsymbol{t}$ Value \\
\hline 5 & $6.23(1.12)$ & $1.87(1.12)$ & 4.36 & $20.99^{* *}$ \\
3 & $5.25(1.59)$ & $2.83(1.72)$ & 2.42 & $7.93^{* *}$ \\
1 & $4.58(1.95)$ & $3.44(1.66)$ & 1.14 & $3.50^{*}$ \\
9 & $4.50(1.80)$ & $3.45(1.81)$ & 1,05 & $3.09^{*}$ \\
7 & $4.08(1.73)$ & $3.88(1.71)$ & 0,20 & .63 \\
2 & $3.61(1.71)$ & $4.55(1.78)$ & -0.94 & $-2.85^{*}$ \\
12 & $3.59(1.81)$ & $4.58(1.72)$ & -0.99 & $-2.91^{*}$ \\
8 & $2.86(1.80)$ & $4.98(1.79)$ & -2.12 & $-6.14^{* *}$ \\
10 & $2.54(1.41)$ & $5.32(1.33)$ & -2.78 & $-10.99^{* *}$ \\
11 & $2.07(1.12)$ & $6.01(1.05)$ & -4.05 & $-19.66^{* *}$ \\
6 & $1.94(0.99)$ & $5.99(1.16)$ & -4.05 & $-20.87^{* *}$ \\
4 & $1.90(1.14)$ & $6.25(0.95)$ & -4.35 & $-22.66^{* *}$ \\
\hline
\end{tabular}

${ }^{*} p<.01 ; * * p<.001$. Note: Difference of means is calculated by subtracting the score of Western Anatolia region from the score of Southeastern Anatolia region; positive scores show that the probability of being from Southeastern Anatolia is high.

The participants' responses to the five questions asked for each of the selected pictures were analysed using paired-sample t-tests. Prior to the analyses, mean scores of the responses for three pictures that represented people from the Southeast and for the five pictures representing people from the West were computed for each question (see Table 2). The results of subsequent analyses revealed that, compared to "Westerners", persons in the photographs representing those of Southeastern origin were perceived to be less likely to have a high level 
of education, to maintain good relationships, to be successful in their career or to be rich. The only characteristic in which the "Southeasterners" outperformed the "Westerners" was in the probability estimates of "being married": Southeasterners were perceived as being more likely to be married than "Westerners". This finding is in clear agreement with the negative stereotypes related to Kurds, which portray them as being firmly attached to such traditional traits as marriage at an early age. Overall, it can be said that findings fitted well with the stereotypes often attributed to Kurdish people by Turkish people.

Table 2 Means, standard deviations and results of t-test analyses of responses regarding the social characteristics of people shown in the photographs in the pilot study $(N=98)$

\begin{tabular}{cccc}
\hline & Southeasterners & Westerners & \\
\cline { 2 - 4 } Probability of: & Mean $(S D)$ & Mean $(S D)$ & t Value \\
\hline Having high-education & $3.89(0.99)$ & $5.58(0.76)$ & $-14.63^{*}$ \\
Having good relationships & $4.14(0.75)$ & $5.09(0.68)$ & $-10.84^{*}$ \\
Being successful in their job & $4.39(0.85)$ & $5.23(0.69)$ & $-10.15^{*}$ \\
Being wealthy & $3.83(0.89)$ & $4.39(0.74)$ & $-6.62^{*}$ \\
Being married & $4.90(1.19)$ & $3.84(0.93)$ & $7.34^{*}$ \\
\hline
\end{tabular}

$* p<.001$

Results of the pilot study showed that the difference between the participants' social distances to each ethnic group were statistically significant $\left(\mathrm{F}_{(5.46,529.92)}=54.69\right)^{1}$. LSD post-hoc analyses revealed that the participants' social distance was very low for the Turkish group, whereas the distances for the Greeks, Romanis and Armenians were the highest, followed closely by Kurds (see Table 3).

Table 3 The pilot and main studies'participants'social distance scores

\begin{tabular}{|c|c|c|c|}
\hline \multicolumn{2}{|l|}{ Pilot Study $(\mathrm{N}=98)$} & \multicolumn{2}{|l|}{ Main Study $(\mathrm{N}=124)$} \\
\hline Ethnic Groups & Mean $(S D)$ & Ethnic Groups & Mean $(S D)$ \\
\hline Turks & $1.05(0.33)_{\mathrm{a}}$ & Turks & $1.11(0.37)_{a}$ \\
\hline Lazs & $1.88(1.22)_{\mathrm{b}}$ & Albanians & $1.94(0.99)_{\mathrm{b}}$ \\
\hline Albanians & $1.97(1.30)_{\mathrm{b}}$ & Lazs & $2.10(1.01)_{\mathrm{bc}}$ \\
\hline Circassians (Çerkez) & $2.00(1.53)_{\mathrm{b}}$ & Circassians (Çerkez) & $2.19(1.21)_{\mathrm{c}}$ \\
\hline Arabians & $3.26(2.10)_{\mathrm{c}}$ & Greeks (Rum) & $3.23(1.74)_{\mathrm{d}}$ \\
\hline Kurds & $3.39(2.30)_{\mathrm{c}}$ & Armenians & $3.24\left(1.77_{\mathrm{d}}\right.$ \\
\hline Greeks (Rum) & $3.60(2.10)_{\mathrm{cd}}$ & Arabians & $3.60(1.64)_{\mathrm{e}}$ \\
\hline Romani & $3.99(2.08)_{\mathrm{d}}$ & Kurds & $4.11(2.10)_{\mathrm{f}}$ \\
\hline Armenians & $4.01(2.30)_{\mathrm{d}}$ & Romani & $4.11(1.62)_{\mathrm{f}}$ \\
\hline
\end{tabular}

Note: All means (within rows) with different subscripts are significantly different at $p<.05 ; S D$ : Standard Deviation.

\section{The Main Study}

\section{Sample}

The main study was conducted with individuals with an active role in recruitment (company owners and partners; senior executives; human resources managers and supervisors; department managers and organizers, namely the decision-makers) in Bursa's automotive ( $\mathrm{n}=$ $102)$ and mechanical $(n=14)$ sectors, and from other industries $(n=8)$. Data was collected

\footnotetext{
${ }^{1}$ As results of Mauchly test showed that the assumption was violated $\left(X^{2}(35)=259.65, p<.05\right)$, Greenhouse-Geisser values were reported.
} 
using the "purposive sampling" method, and total of 124 people (67 female, 57 male) participated in the study. Participants were not compensated in any form. Age range of the participants was wide, ranging from 23 to 60 , although half of the participants were aged between 23 and 39 years. Most of the participants reported that they were working in largescale $(n=52 ; 41.94 \%)$ or medium-scale $(n=47 ; 37.90 \%)$ organisations, while the other participants reported that they were in small- or micro-scale organisations $(n=24 ; 19.35 \%){ }^{2}$ The maximum number of workers who occupied the manager position in these organisations in which participants worked was ten. Most of the participants (104 out of 124) stated that they defined themselves as members of the Turkish group, while 12 participants stated that they were members of both Turkish and another ethnic group. Only one participant stated that he saw himself as a member of the "Kurd" group. Four participants did not specify any group identities.

\section{Instruments}

Fictional Curriculum Vitaes (FCVs). To measure the discrimination tendencies of the decision-makers towards candidates of Southeastern Anatolian origin from those of other regions in an employee selection process, eight FCVs (three representing Southerners and five representing candidates from other regions) were prepared for eight fictional male mechanical engineers looking for a job. The reason for using only males as applicants in the present study was that there are few women in Turkey with degrees in mechanical engineering.

Each FCV included one of the photographs selected in the pilot study and additional information that was used to create the image of an applicant born and high school-educated in the Southeast region (or in regions other than the Southeast) of Turkey. Both the birthplace and the city of high school graduation for the three supposed applicants from the Southeast region were purposely selected as Diyarbakır, Şanlıurfa and Siirt, all of which are cities of Turkey that have significant Kurdish populations. For the other so-called applicants, cities in different regions of Turkey (Ankara-Central; Izmir-West; Antalya-South, Aydın-Southwest; and Trabzon-Northeast) were used for their birthplace and the city of high-school graduation. When selecting cities for the FCVs of the candidates from the other regions, cities in the Eastern Anatolia region were purposely avoided, as some are home to a sizable number of Kurdishorigin citizens.

On the FCVs, all other factors that could affect the decisions of the decision-makers (age, education, job experience, hobbies) were kept as equal as possible in order to make the candidates' background information appear to be similar to each other by participants. An attempt was made to eliminate any possible confounding effect related to university education by depicting all candidates as graduates of one of the three most prestigious universities in Turkey in the field of mechanical engineering. Furthermore, in order to equalize candidates' job experience, all FCVs included similar information presenting each candidate as having worked previously for a large and well-known firm. A similar approach was followed regarding the applicants' foreign language proficiency levels and hobbies.

Applicant Evaluation Forms 1 and 2. Two separate forms were given to participants and they were asked to answer two questions: In the first form, "According to organisational values,

\footnotetext{
2 Organisation size groupings were based on the European Union SME definition. Large-scale organisations are organisations with 250 or above employees; medium-scale organisations are those with 50-249 employees; and organisations with 10-49 employees and 0-9 employees are known as small-scale and micro-scale organisations, respectively.
} 
what is the probability of hiring this candidate?". In the second form, participants were asked to rate the recruitment probability of each candidate by drawing upon their own personal values. Both evaluations were made using a 7 -point scale $(1=$ Totally disagree, $7=$ Totally agree).

Identification Scale. The "In-group Identification Scale" was used to determine the level to which the decision-makers identified with the Turkish group. This scale was developed by Kirshler, Palmonari and Pombeni (1994), and adapted to the Turkish language by Hortaçsu (2000). For the present study, the scale's internal reliability was very high $(\propto=.93)$.

Social Dominance Orientation Scale. Sidanius, Pratto and Mitchell's (1994) scale was used for measuring the SDO levels of participants. This scale was adapted to the Turkish language by Karaçanta (2002). For the present study, the scale's internal validity value was reasonably high $(\propto=.87)$.

Bogardus Social Distance Scale. The form used in the pilot study was also used in this study (see, Bogardus, 1925).

Perceived Equal Occupational Opportunity Scale. Chung and Harmon's (1999) scale developed for measuring the possible effects of ethnicity in job discrimination for those exposed to ethnic discrimination was used to measure people's perceptions of the level of equality in job opportunities in the workplace on a 5 -point scale $(1=$ Totally disagree, $5=$ Totally Agree). Samples of the thirteen items of the scale are: "It's easier for Turks to get ahead than other ethnic group members" and "Personnel decisions are primarily based on employee training and experience rather than ethnicity". The items were presented after an instruction that asked participants to rate each item by considering their current organisations. Reliability of the scale was acceptable $(\propto=.79)$.

Demographic Information Form. Participants were asked about their age, gender, birthplace, job position, ethnic group(s) that they belong to and whether they had received any kind of education related to workplace discrimination. In relation to the ethnic identity question, although participants were free to write down more than one ethnic identity, 104 of the 124 participants in decision-maker positions reported their identity to be Turkish, without mentioning any other identity. The rest of the participants $(n=23)$ preferred to mention their dual (or multiple) identities (for example, "I am a Bulgarian-Turkish immigrant" or "I am of Bosnian-Turkish origin"). Only one participant mentioned his/her Kurdish identity together with another identity.

\section{Procedure}

Participants were met individually in their offices by appointment during which time they were asked to examine the CVs for approximately five minutes once response confidentiality and anonymity were guaranteed. They were told that, if they volunteer, they would take part in a social psychology study whose aims would be explained at the end of the session for the sake of the study. They were then handed evaluation forms 1 and 2, respectively, and asked to evaluate the recruitment probability of each applicant. After the completion of these two forms, the rest of the scales were also given to the participants separately in a questionnaire form. At the end of each session, participants were asked to place their questionnaires in sealable envelopes and to add them randomly to a pile of other envelopes by themselves. Each session lasted one hour on average and was followed by a debriefing about the aims of the study.

\section{Results of the Main Study}

In order to test the present study's hypotheses, four new variables were computed by calculating the mean evaluation scores of the three Southeast Anatolian-origin candidates and 
the five candidates from other regions, according to organisational and personal values. The four variables that were used as dependent variables of the study were named recruitment probability of candidates from the Southeast (separately for organisational and personal values); and recruitment probability of candidates from other regions (separately for organisational and personal values). For the mean scores and standard deviations of all variables used in the analyses, see Table 4.

Table 4 Descriptive statistics of the main variables of the Main Study $(N=123)$

\begin{tabular}{ccc} 
Variables & Mean & Standard Deviation \\
\hline $\begin{array}{c}\text { Recruitment Probability of Candidates from Other } \\
\text { Regions for organisational values }\end{array}$ & 5.47 & .91 \\
$\begin{array}{c}\text { Recruitment Probability of Candidates from Southeast for } \\
\text { organisational values }\end{array}$ & 4.69 & 1.54 \\
$\begin{array}{c}\text { Recruitment Probability of Candidates from Other } \\
\text { Regions for personal values }\end{array}$ & 5.53 & .91 \\
$\begin{array}{c}\quad \text { personal values } \\
\text { Recruitment Probability of Candidates from Southeast for }\end{array}$ & 4.47 & 1.63 \\
$\quad \begin{array}{c}\text { Identification with Turkish Group } \\
\text { Social Dominance Orientation }\end{array}$ & 3.93 & .77 \\
Perceived Equal Opportunities in Employment & 2.57 & .01 \\
\hline
\end{tabular}

\section{Test of the Four Hypotheses}

Social Distance from Ethnic Groups. To test the first hypothesis that asserted a significant difference between the social distances felt towards the Turkish and Kurdish ethnic groups, participants' social distance from several ethnic groups were compared with repeated measures analysis of variance. The results of the main study also showed that the differences between the decision-makers' social distance from each ethnic group were statistically significant $\left(F_{(5.21}\right.$, $\left.{ }_{640.33)}=103.28\right) .{ }^{3}$ LSD post hoc analyses revealed that the decision-makers' social distance was closest to the Turkish group, and greatest from the Kurdish and Romani groups (see, Table 3). This set of results highlights Kurds as one of the most disliked ethnic groups among decisionmakers. In this regard, the first hypothesis that asserted a significant difference between the social distances felt by the decision-makers towards the Turkish and Kurdish ethnic groups was supported.

Correlation Analyses. For the test of the second and fourth hypothesis, the relationships between the main variables of the study were analysed with a Pearson's correlation (See, Table 5 ). The results showed that SDO was negatively related with the recruitment probability of candidates from the Southeast only at a personal level. In this regard, the second hypothesis seeking relationships both at personal and organisational levels was partially confirmed. In line with expectations of the third hypothesis, the results revealed that perceived equal occupational opportunities were related positively with the recruitment possibilities of candidates from the Southeast, both at organisational and personal levels

\footnotetext{
${ }^{3}$ Results of Mauchly test of the sphericity showed that the assumption was violated $\left(X^{2}(35)=188.44, p<.05\right)$. For this reason, we reported Greenhouse-Geisser values, as suggested by Field (2010: 461).
} 
Table 5 The inter-correlations between the variables used in Study $2(N=123)$

\begin{tabular}{|c|c|c|c|c|c|c|c|c|c|c|c|}
\hline & 1 & 2 & 3 & 4 & 5 & 6 & 7 & 8 & 9 & 10 & 11 \\
\hline Age (1) & -- & $-.20^{*}$ & -.13 & -.12 & -.02 & -.11 & -.01 & -.09 & -.05 & -.05 & .02 \\
\hline Education (2) & & -- & -.11 & -.12 & .17 & .14 & .13 & .12 & -.16 & $-.20^{*}$ & -.06 \\
\hline Social distance from Turks (3) & & & -- & $.22^{*}$ & .02 & -.08 & .00 & -.07 & -.01 & .16 & -.07 \\
\hline Social distance from Kurds (4) & & & & -- & .03 & -.17 & .08 & $-.26^{* *}$ & $.23^{* *}$ & $.53^{* *}$ & -.06 \\
\hline $\begin{array}{l}\text { Recruitment Probability of } \\
\text { Candidates from Other } \\
\text { Regions for organisational } \\
\text { values (5) }\end{array}$ & & & & & -- & $.36^{* *}$ & $.83^{* *}$ & $.31^{* *}$ & $.22^{*}$ & .02 & -.13 \\
\hline $\begin{array}{l}\text { Recruitment Probability of } \\
\text { Candidates from Southeast for } \\
\text { organisational values (6) }\end{array}$ & & & & & & -- & $.31^{* *}$ & $.81^{* *}$ & .06 & -.06 & $.21^{*}$ \\
\hline $\begin{array}{l}\text { Recruitment Probability of } \\
\text { Candidates from Other } \\
\text { Regions for personal values ( } 7)\end{array}$ & & & & & & & -- & $.24^{* *}$ & .13 & .05 & -.15 \\
\hline $\begin{array}{l}\text { Recruitment Probability of } \\
\text { Candidates from Southeast for } \\
\text { personal values (8) }\end{array}$ & & & & & & & & -- & .01 & $-.20^{*}$ & $.22^{*}$ \\
\hline Identification with Group (9) & & & & & & & & & -- & $.38^{* *}$ & -.01 \\
\hline $\begin{array}{l}\text { Social Dominance Orientation } \\
(10)\end{array}$ & & & & & & & & & & -- & -.14 \\
\hline $\begin{array}{l}\text { Perceived Occupational } \\
\text { Opportunity (11) }\end{array}$ & & & & & & & & & & & -- \\
\hline
\end{tabular}

It was also found that participants' social distance to Turks was not related to any other social psychological variable, whereas the social distance from Kurds was positively related with identification with the Turkish group. Another important finding was that an identification with the Turkish group was positively correlated with social distance from Kurds - as the gatekeeper's level of identification with Turkish group increases, the social distance felt from Kurds also increases. The identification variable was also correlated significantly to the recruitment probability of candidates from other regions. The gatekeeper's SDO scores were positively correlated with social distance from Kurds, while negatively correlated with the recruitment probability of candidates from the Southeast.

Comparison of Recruitment Probabilities of Candidates from the Southeast and from Other Regions. For the test of the third hypothesis the recruitment possibilities of candidates from the Southeast and other candidates, were compared with paired-sample t-tests.? Results showed that, for both organisational $\left(t_{(1,124)}=5.80, p<.001\right)$ and personal $\left(t_{(1,124)}=6.14, p<.001\right)$ evaluations, decision-makers gave lower chances to candidates from the Southeast (for organisational evaluations $M=4.70, S D=1.53$; for personal evaluations, $M=4.47, S D=1.62$ ) than to candidates from other regions (for organisational evaluations $M=5.46, S D=0.91$; for personal evaluations $M=5.53, S D=0.91$ ). These findings confirmed the third hypothesis.

Predictors of Candidates' Chance of Recruitment as Perceived by Decision-makers. In order to determine which variables predict the recruitment probability of candidates, a series of multiple regression analyses were carried out separately for both scores in the organisationbased evaluations and personal evaluations. In all analyses, the variables of identification for the group, SDO, perceived equal occupational opportunity and the social distance from Turks/Kurds (depending on the evaluations made) were included in the equation by the "enter" technique. 
For the organisational evaluations, the results showed that only identification with the group variable predicted the recruitment possibility of candidates from other regions: as the gatekeeper's identification with a Turkish identity increases, so does the recruitment probability of a candidate from other regions of Turkey (see Table 6). In the recruitment possibility of candidates from the Southeastern region, the perceived equal occupational opportunity was the strongest predictor of the decision-makers' opinions: if decision-makers believe that their institutions implement an equal opportunity policy, the recruitment possibility of a candidate from Southeast region increases.

Table 6 Results of Hierarchical Regression Analyses of the Evaluation Scores of Recruitment Probability of Applicants

\begin{tabular}{|c|c|c|c|c|}
\hline & \multicolumn{2}{|c|}{ For Organisational Level } & \multicolumn{2}{|c|}{ For Personal Level } \\
\hline & $\begin{array}{l}\text { Recruitment } \\
\text { Probability of } \\
\text { Applicants } \\
\text { from Other } \\
\text { Regions }\end{array}$ & $\begin{array}{l}\text { Recruitment } \\
\text { Probability of } \\
\text { Applicants } \\
\text { from } \\
\text { Southeastern } \\
\text { Anatolia }\end{array}$ & $\begin{array}{l}\text { Recruitment } \\
\text { Probability of } \\
\text { Applicants } \\
\text { from Other } \\
\text { Regions }\end{array}$ & $\begin{array}{l}\text { Recruitment } \\
\text { Probability of } \\
\text { Applicants } \\
\text { from } \\
\text { Southeastern } \\
\text { Anatolia }\end{array}$ \\
\hline Predictors & $\beta$ & $\beta$ & $\beta$ & $\beta$ \\
\hline $\begin{array}{l}\text { Identification with the } \\
\text { Turkish Group } \\
\text { Social Dominance }\end{array}$ & $.23^{*}$ & .09 & .14 & .09 \\
\hline $\begin{array}{l}\text { Orientation } \\
\text { Perceived Equal }\end{array}$ & -.10 & -.07 & -.05 & $-.21 *$ \\
\hline $\begin{array}{l}\text { Occupational Opportunity } \\
\text { Social distance from }\end{array}$ & -.15 & $.21^{*}$ & -.16 & $.20^{*}$ \\
\hline Turkish/Kurdish Groups & .09 & .04 & .10 & .01 \\
\hline F Value: & $2.46^{*}$ & $1.78^{*}$ & 1.64 & $2.91 *$ \\
\hline Total $\mathrm{R}^{2}$ (Adj.): & .05 & .03 & .02 & .06 \\
\hline
\end{tabular}

$* p<.05 ; * * p<.01$

In results from the regression analysis of scores of personal evaluations of the recruitment probability of candidates from other regions, none of the variables predicted significant variance. However, for the recruitment probability of candidates from the southeast, the results showed that SDO and perceived equal occupational opportunity variables were able to predict a significant variance: An equal recruitment policy in the organisation increases the chance of recruitment for candidates from the south-eastern region, whereas the decisionmakers' SDO decreases their chance of being recruited.

\section{Discussion}

This study has investigated ethnic discrimination tendencies in the workplace for the Kurdish ethnic group, taking the city of Bursa as an example. By creating FCVs, it was determined whether members of the Kurdish ethnic group had equal access to employment opportunities.

The present study took advantage of having data from two different samples from the same city (one from ordinary citizens and the other one from the decision-makers of industrial firms) regarding their social attitudes towards Kurds in the form of social distance from this ethnic group. Findings from these samples seem to confirm the observations that these attitudes are not positive when compared to attitudes towards other ethnic groups. Moreover, the social distance felt by the decision-makers to Kurds was larger than the general sample's perceptions, pointing out that prejudice against Kurds in Turkish people could be higher in the workplaces. The expectation that this social distance between the decision-makers and the Kurdish ethnic 
group would have a strong influence on the equal working rights of ethnically Kurdish citizens was found to be supported. Decision-makers, who play an important social role in the provision of employment and career opportunities to individuals and groups in society seem to carry a strong prejudice against the Kurdish ethnic group. Although it is an indirect one, another confirmation of this argument comes from the finding that the lowest level of social distance felt by the decision-makers was seen to be towards the Turkish ethnic group.

Findings showed that, among the decision-makers, Kurdish identity was reported by only one participant and it was stated as part of a dual identity. Given that the Kurdish ethnic group constitutes approximately 10 per cent of the total Turkish population, the fact that the sample included almost no representatives of this group in the role of gatekeeper fits with the above-mentioned picture. In the Constitution and the laws of Turkey, all citizens are rendered equal and are expected to have equal access to work. Contrary to these legal prescriptions, however, in the course of this research it became apparent that there was no representative of the Kurdish ethnic group in a managerial role, showing that the level of equal representation or actual equality in this sector is far from the ideal. Even the possibility of concealment of this identity by some participants in the group of decision-makers does not challenge the argument stated above as the motivation for such a tendency should be seen as a result of disturbances felt by Kurds in their workplaces.

In the main study based on the FCVs, the employment possibility of candidates who were perceived to be from the Southeast was found to be lower than that of the other candidates in respect to institutional values. When the potential for employment of the candidates was examined in relation to the personal views of the decision-makers, the candidates who were thought to be from the Southeast were less likely to gain employment than the other candidates. It should be noted that even though there was no explicit information on the applicants' ethnicity FCV's, the information presented about the birthplace, the city of high-school education and the photographs were sufficient enough to create an impression that was effective in lessening the chance of a candidate being considered for employment.

Following a multi-level (individual and institutional levels) approach, this study has shown that employee selection processes are prone to basic social psychological factors such as SDO and in-group identification, and SDO in particular seems to be an effective variable for the prediction of discriminative tendencies at an individual level. In this study, as decisionmakers' SDOs increased, the tendency to see the recruitment chance of Southeasterners as low increased. As proposed by SDT, people with high SDO are motivated to protect and maintain the status hierarchies that are prevalent in society, and the findings of this study have identified this tendency also in employee selection processes.

In-group identification, as one of the basic concepts of SIA, is an important condition for the emergence of the phenomenon of in-group favouritism. As the individuals' level of identification increases, they tend to allocate resources to a disproportionate degree to in-group members. In the present study, however, it was found that in-group identification was related only to the preferences for "Turkish" candidates. It would seem that in-group identification works in a rather indirect way, in that a high-level of identification did not directly prevent outgroup members (Southeasterners) from finding employment, but rather made finding employment more possible for the "Turkish" candidates.

When viewed together, SDO and in-group identification seem to represent two sides of the same coin: SDO is a direct way of preventing upward mobility among out-group members, whereas in-group identification is a subtle, indirect way of keeping them where they are by filling positions with in-group members. On the whole, however, these two basic variables work to strengthen the boundaries within status hierarchies. 
The pessimistic impression left by the above-mentioned findings was countered to some degree by the findings related to the variable of perceived equal occupational opportunity. This variable was found to be among the most powerful predictors of discriminative tendencies among decision-makers. This study has shown that for those from the Southeast of Turkey, the probability of finding a position increases as a function of the decision-makers' equal opportunity perceptions in relation to their organisations. More interestingly, if the gatekeeper believed that his/her organisation applied an equality policy, this also affected the chances of "Turkish" candidates in a negative way. In summary, if an equal opportunity policy is in effect in an organisation, decision-makers seem to be prevented from behaving in a discriminative way, whether directly or indirectly. These findings are quite consistent with the findings of Umphress et al. (2008) showing that explicit directives from an authority figure are effective in curbing discriminative tendencies.

The above-mentioned findings can be interpreted from both SIA and SDT perspectives. From an SIA perspective, an equal opportunity policy can be considered as a "group norm", which is the most effective way of regulating the potentially diverse behaviours of members of the in-group (Turner, 1999). Accordingly, if equal opportunity policies are defined as the norm in an organisational culture, it may be asserted that it is a very effective way of curbing discriminative behaviours among decision-makers. From the SDT perspective, equal opportunity policies can be regarded as by-products of HA-LMs. As such myths are the counter forces of HE-LMs, they help members of minority groups improve their lives in the face of highly dominating societal and institutional structures (Sidanius and Pratto, 1999).

\section{Conclusion}

Drawing upon multi-level theories, this study has pointed out that ethnic discrimination is a rather complex phenomenon that encompasses several factors, ranging from the beliefs/motivations of the individual decision-makers to organisational/societal structure. The richness and volume of the data used in the present study makes it possible to assert that reflections of ethnic discrimination are quite elusive. In this regard, the use of indirect techniques as the one used in this study, namely FCVs, can be considered an effective alternative approach to understanding individual-level motivations and the tendencies that influence employee selection processes.

The findings of this study are important in that they reveal some of the possible barriers to the construction of social equality. On the other hand, findings identified a possible solution to the problem in organisations: if decision-makers are aware of an equal opportunity policy in their organisations, this may prevent them from behaving in a discriminative way. As diversity training is supposed to have positive results in reducing discrimination (King et al. 2012), it seems helpful to take advantage of such programs in reducing discriminative tendencies of decision-makers by pointing out to them the norms of their organisations. A close surveillance of the selection procedures may also increase the chance of creating equal opportunities for all.

The limitations of the present study include its predominant focus on organisations in the automotive sector in the city of Bursa. What an extension of the sample to include decisionmakers from other sectors would bring to the results is an open question. Furthermore, although performing the study in only one city within Turkey might make the findings appear to be parochial, the use of state-of-the-art social psychological theories to develop testable hypotheses paves the way for evaluating our findings in relation to other societies. Lastly, it should be noted that the use of realistic, non-standardized photographs on the CVs is another limitation of the present study as social categorization is sensitive to low-level physical features of stimuli. 


\section{References}

Ajrouch K.J., Reisine, S., Lim, S. Sohn, W. and Ismail, A. (2010). "Perceived everyday discrimination and psychological distress: does social support matter?". Ethnicity \& Health, 15, (4): 417- 434.

Akkan, B.E., Deniz, B.D. and Ertan, M. (2011). Sosyal Dışlanmanın Roman Halleri (Romani States of Social Exclusion). Istanbul: Bosphorus University Social Policy Forum.

Allport, G.W. (1954). The Nature of Prejudice. Cambridge, MA: Addison-Wesley

Altuntaş, B. (2014). “Zorunlu Kürt Göçünü Kentsel Yoksulluk ve Dişlanma Ekseninde Sosyal Politika Perspektifinden Yeniden Düşünmek (Rethinking Obligatory Kurdish Migration from a Social Policy Perspective in the Context of Urban Poverty and Exclusion)," in B. Altuntaş (ed), Dezavantajlı Gruplar ve Sosyal Politika (Disadvantaged Groups and Social Policy). 137-158, Ankara: Nobel Akademik Yayıncılık Eğitim Dağıtım Ltd. Şti.

Andrews, P.A. (1992). Türkiye'de Etnik Gruplar (Ethnic Groups in Turkey). Ankara: Ant Yayınları.

Benner, A. D., Wang, Y., Shen, Y., Boyle, A. E., Polk, R., and Cheng, Y.-P. (2018).

"Racial/Ethnic discrimination and well-being during adolescence: A meta-analytic review." American Psychologist, 73(7): 855-883.

Blank, R.M., Dabady, M. and Citro, C.F. (2004). Measuring Racial Discrimination. Washington D.C: The National Academy Press.

Bogardus, E.S. (1925). “Measuring social distances". Journal of Applied Sociology, 9: 299308.

Buğra, A. and Keyder, Ç. (2003). "New Poverty and the Changing Welfare Regime of Turkey. Report prepared for the United Nations Development Programme". Available at: http://www.tr.undp.org/content/dam/turkey/docs/povreddoc/UNDP-TRnew_poverty.pdf

Chung, Y., Barry, and Harmon, L.W. (1999). "Assessment of perceived occupational opportunity for Black Americans". Journal of Career Assessment, 7: 45-62.

Corning, A. F. (2002). "Self-esteem as a moderator between perceived discrimination and psychological distress among women", Journal of Counseling Psychology, 49(1): 117.

Dadfar H. and Gustavsson, P. (1992), "Competition by effective management of cultural diversity: the case of international construction projects", International Studies of Management \& Organization, 22, (4): 81-92.

Deitch, E. A., Barsky, A., Butz, R. M., Chan, S., Brief, A. P. and Bradley, J. C. (2003).” Subtle yet significant: the existence and impact of everyday racial discrimination in the workplace." Human Relations, 56 (11): 1299-324. 
Dovidio, J.F. (2001). "On the nature of contemporary prejudice: the third wave". Journal of Social Issues, 57: 829-849.

Dovidio, J.F. and Hebl, M.R. (2005). Discrimination at the Level of Individual: Cognitive and Affective Factors. in R.L. Dipboye and A. Colella (Ed.), Discrimination at Work: 1134. New Jersey: Lawrence Erlbaum Associates.

Elmslie B. and Sedo, S. (1996), "Discrimination, social psychology, and hysteresis in labor market", Journal of Economic Psychology, 17, (4): 465-478.

Fearfull, A., and Kamenou, N. (2010). "Work and career experiences of ethnic minority men and women." Equality, Diversity and Inclusion, 29(4): 325-331.

Feng, D. and Xu L. (2014), "The relationship between perceived discrimination and psychological distress among Chinese pulmonary tuberculosis patients: The moderating role of self-esteem". Psychology Health and Medicine, 20 (2):1-9.

Field, A. (2010). Discovering Statistics Using IBM SPSS Statistics. Los Angeles: Sage.

Fiske, S.T. (1998). Stereotyping, Prejudice, and Discrimination. in D. T. Gilbert, S. T. Fiske, and G. Lindzey (Ed), The Handbook of Social Psychology: 357-411. New York: McGraw-Hill.

Fiske, S.T., Amy, J.C., Cuddy, A.J.C., Glick, P. and Xu, J. (2002). "A model of (Often Mixed) stereotype content: Competence and warmth respectively follow from perceived status and competition". Journal of Personality and Psychology, 82: 878-902.

Follmer, K. B., and Jones, K. S. (2017). "Stereotype content and social distancing from employees with mental illness: The moderating roles of gender and social dominance orientation," Journal of Applied Social Psychology, 42: 492-504.

Gaddis, S. M. (2018). An Introduction to Audit Studies in the Social Sciences. in S. M. Gaddis (ed.), Audit Studies: Behind the Scenes with Theory, Method, and Nuance: 3-44. Ghent: Springer.

Gagnon, A., and Bourhis, R. Y. (1996). "Discrimination in the minimal group paradigm:

Social identity or self-interest?", Personality and Social Psychology Bulletin, 22(12): 1289-1301.

Glasford, D. E., Dovidio, J. F. , and Pratto, F. (2009). "I continue to feel so good about us: Ingroup identification and the use of social identity-enhancing strategies to reduce intragroup dissonance", Personality and Social Psychology Bulletin, 35 (4): 415-427.

Göregenli, M. (2012). “Temel Kavramlar: Önyarg1, Kalıpyargı ve Ayrımcılık (Basic Concepts: Prejudice, Stereotype and Discrimination)", in K. Çayır and M. Ayan Ceyhan (ed.), Ayrımcılık Çok Boyutlu Yaklaşımlar (Discrimination Multidimensional Approaches). 17-28. İstanbul: İstanbul Bilgi Üniversitesi Yayınları. 
Hassan, G., Rousseau, C. and Moreau, N. (2013), "Ethnic and religious discrimination: The multifaceted role of religiosity and collective self-esteem", Transcultural Psychiatry, 50 (4): 475-492.

Hogg, M. A., Abrams, D., Otten, S. and Hinkle, S. (2004). "The social identity perspective: Intergroup relations, self-conception, and small groups," Small Group Research, 35(3): 246-276.

Hogg M. A. and Reid S. A. (2006). "Social identity, self-categorization, and the communication of group norms," Communication Theory, 16(1): 7-30.

Hogg, M.A. and Vaughan, G.M. (2007). Sosyal Psikoloji (Social Psychology). Ankara: Ütopya Yayınevi.

Hornsey, M. J. (2008). "Social identity theory and self-categorization theory: A historical review," Social and Personality Psychology Compass, 2(1): 204-222.

Hortaçsu, N. (2000). "Inter-group relations in a changing political context: the case of veiled and unveiled university students in Turkey". European Journal of Social Psychology, 30: 733-744.

Huddy, L. (2004). "Contrasting theoretical approaches to intergroup relations". Political Psychology, 25: 947-967.

ILO ITC. (2009). Towards an Inclusive Society: Tackling Discrimination in the World of Work. Italy: Course Papers, International Labour Organisation, International Training Centre.

International Covenant on Economic, Social and Cultural Rights. United Nations. (n.d.). Retrieved from http://www.ohchr.org/EN/ProfessionalInterest/Pages/CESCR.aspx

International Labour Organization ILO, International Labour Standards. Retrieved from: http://ilo.org/global/standards/introduction-to-international-labourstandards/conventions-and-recommendations/lang--en/index.htm

Jackson, L. A., and Harnish, R. J. (1996). "Achieving positive social identity: social mobility, social creativity, and permeability of group boundaries", Journal of Personality and Social Psychology, 70(2): 241-254.

Jackson, S. E. Brett, J. F., Sessa, V. I., Cooper, D. M., Julin, J. A., and Peyronnin, K. (1991). "Some differences make a difference: Individual dissimilarity and group heterogeneity as correlates of recruitment, promotions, and turnover." Journal of Applied Psychology, 76: 675-689.

Jasinskaja-Lahti, I., Liebkind, K., and Perhoniemi, R. (2007). "Perceived ethnic discrimination at work and well-being of immigrants in Finland: The moderating role of employment status and work-specific group-level control beliefs." International Journal of Intercultural Relations, 31: 223-242. 
Karaçanta, H.Ş. (2002). Üniversite öğrencilerinin sosyal baskınlık yönelimi ve başka bazı değişkenler açısından karşılaştırılması (Comparison of university students in terms of social dominance orientation and some other variables). Unpublished $\mathrm{PhD}$ thesis, Ankara Üniversitesi Sosyal Bilimler Enstitüsü, Ankara.

Kteily, N. S., Sidanius, J., and Levin, S. (2011). "Social dominance orientation: Cause or 'mere effect'?: Evidence for SDO as a causal predictor of prejudice and discrimination against ethnic and racial outgroups," Journal of Experimental Social Psychology, 47(1): 208214.

King, E. B., Hebl, M. R., and Beal, D. J. (2009). "Conflict and cooperation in diverse workgroups.” Journal of Social Issues, 65: 261-285.

King, E.B., Dawson, J.F., Kravitz, D.A. and Lisa M. V. Gulick, L.M.V. (2012). “A multilevel study of the relationships between diversity training, ethnic discrimination and satisfaction in organizations". Journal of Organizational Behavior, 33: 5-20.

Kirshler, E., Palmonari, A. and Pombeni, M.L. (1994). "Social categorization processes between groups: A step into adolescents peer-groups". Journal of Social Psychology, 24: 541-563.

KONDA Araştırma ve Danışmanlık (2006). Biz Kimiz? Toplumsal Yapı Araştırması (Who are We? Social Structure Survey). Milliyet, Retrieved from: http://www.konda.com.tr/tr/raporlar/2006 09

KONDA Araştırma ve Danışmanlık (2010). Kürt Meselesinde Algı ve Beklentiler (Perception and Expectations in the Kurdish Question). Available at: https://konda.com.tr/tr/rapor/kurt-meselesinde-algi-ve-beklentiler/,

Lang, K. (2007). Poverty and Discrimination. Princeton, NJ: Princeton University Press.

Lordoğlu K. and Arslan M. (2012). "Türkiye işgücü piyasalarında etnik bir ayrımcıllık var midır? (Is there any ethnic discrimination in Turkey's labor market?)", Çalışma ve Toplum, 2: 117-146.

Macionis, J. J. (2013). Sosyoloji (Sociology). Ankara: Nobel Akademik Yayıncılık Eğitim Danışmanlık Tic. Ltd. Şti.

Marchington, M and Wilkinson, A. (2002). People Management and Development: Human Resource Management at Work. London: IPD House.

Michinov, N., Dambrun, M., Guimond, S., and Méot, A. (2005). "Social dominance orientation, prejudice, and discrimination: A new computer-based method for studying discriminatory behaviors," Behavior Research Methods, 37(1): 91-98.

Milliken, F. J., and Martins, L. L. (1996). "Searching for common threads: Understanding the multiple effects of diversity in organizational groups." Academy of Management Review, 21: 402-433. 
Morris, M. and Fiske, S.T. (2009). Inclusive leadership, stereotyping and the brain. in: Inclusive Leadership, Stereotyping and the Brain, The Sanford C. Bernstein and Co. Center for Leadership and Ethics. Retrieved from Columbia University website: http:/www8.gsb.columbia.edu/leadership/sites/leadership/files/bernstein_inclusive_le adership_report.pdf

Mummendey, A., Kessler, T., Klink, A. Mielke, R. (1999). "Strategies to cope with negative social identity: predictions by social identity theory and relative deprivation theory", Journal of Personality and Social Psychology, 76 (2): 229-245.

Neumark, D. (2011). "Detecting Discrimination in Audit and Correspondence Studies". The Journal of Human Resources. 47: 4.

Paker, M. (2012). Psikolojik Açıdan Önyargı ve Ayrımcılık (Psychological Prejudice and Discrimination). in K. Çayır and M. Ayan Ceyhan (Ed.), Ayrımcilık: Çok Boyutlu Yaklaşımlar (Discrimination: Multi-level approaches), İstanbul: İstanbul Bilgi Üniversitesi Yayınları.

Perreault, S. and Bourhis, R.Y. (1999). "Ethnocentrism, social identification, and discrimination," Personality and Social Psychology Bulletin, 25 (1): 92-103.

Pratto, F., Sidanius, J., Stallworth, L.M. and Malle, F.B. (1994). "Social Dominance Orientation: a personality variable predicting social and political attitudes". Journal of Personality and Social Psychology, 67: 741-763.

Pratto, F., Sidanius, J. and Levin, S. (2006). "Social Dominance Theory and the dynamics of intergroup relations: Taking stock and looking forward". European Review of Social Psychology, 17: 271-370.

Saraçoğlu, C. (2011). Şehir, Orta Sinıf ve Kürtler (City, Middle Class and Kurds), İstanbul: İletișim.

Sidanius, J., Liu, J. H., Shaw, J. S. and Pratto, F. (1994a). "Social dominance orientation, hierarchy attenuators and hierarchy enhancers: Social dominance theory and the criminal justice system, " Journal of Applied Social Psychology, 24(4): 338-366.

Sidanius, J., Pratto, F. and Mitchell, M. (1994b). "In-group identification, social dominance orientation, and differential intergroup social allocation”. Journal of Social Psychology, 134: 151-167.

Sidanius, J. and Pratto, F. (1999). Social Dominance. Cambridge: Cambridge University Press.

Stephan, W. G., and Stephan, C. W. (2000). “An Integrated Threat Theory of Prejudice.” in S. Oskamp (ed.), Reducing Prejudice and Discrimination. The Claremont Symposium on Applied Social Psychology: 23-45. Manwah, NJ: Lawrence Erlbaum Associates Publishers.

Stephan, W. G., and Renfro, C. L. (2002). "The Role of Threat in Intergroup Relations," in D. M. Mackie and E. R. Smith (ed.), From Prejudice to Inter-group Emotions: Differentiated Reactions to Social Groups: 191-207. New York, NY: Psychology Press. 
Tajfel, H. and Turner, J.C. (1979). An integrative theory of intergroup conflict. in W.G. Austin and S. Worchel (ed.), The social psychology of intergroup relations: 33-47. Monterey CA: Brooks-Cole.

Taylor P., McLoughlin C., Meyer D and Brooke E., (2013). "Everyday discrimination in the workplace, job satisfaction and psychological wellbeing: Age differences and moderating variables. Ageing \& Society, 33 (7): 1105-1138.

Triana, M., Jayasinghe, M. and Pieper, J. (2015). "Perceived workplace racial discrimination and its correlates: A meta-analysis”. Journal of Organizational Behavior, 36: 491-513.

TÜIK, (2019). Nüfus İstatistikleri (Demographic Statistic). Available at: http://www.tuik.gov.tr/UstMenu.do?metod=temelist

Turner, J.C. (1999). "Some Current Issues in Research on Social Identity and Selfcategorization Theories". in N. Ellemers, R., Spears, and B. Doosje (ed.) "Social identity, context, commitment, content": 6-34. Oxford: Blackwell.

Umphress, E.E., Simmons, A.L., Boswell, W.R. and Triana, M. (2008). "Managing discrimination in selection: The impact of directives from an authority and social dominance orientation". Journal of Applied Psychology, 93: 982-993.

Van-Laer, K. and Janssens M. (2011). "Ethnic minority professionals' experiences with subtle discrimination in the workplace". Human Relations, 64 (9): 1203-1227.

Wen H. and Madera, J. M. (2013). "Perceptions of hospitality careers among ethnic minority students", Journal of Hospitality, Leisure, Sport \& Tourism Education. 13: 161-167.

Wyer, N. A. (2010). "Salient egalitarian norms moderate activation of out-group approach and avoidance”, Group Processes \& Intergroup Relations, 18 (2): 151-165. 